\title{
Prenatal y póstumo: Escrituras impotentes en Invenciones del recuerdo de Silvina Ocampo
}

\author{
ROMINA MAGALLANES Universidad Nacional de Rosario - CONICET, Argentina \\ ORCID 0000-0002-6817-1477 \\ romina_magallanes@yahoo.com.ar
}

\section{Resumen}

Invenciones del recuerdo, de Silvina Ocampo, forma parte del corpus póstumo de la autora. En 2006 Sudamericana editó por primera vez esta obra al cuidado de Ernesto Montequin, que ha sido considerada como un texto autobiográfico.

Este trabajo propone una lectura de Invenciones del recuerdo que no aborda la obra desde esa perspectiva sino como un texto que expone una impotencia escrituraria a partir de la expresión «prenatal» que abre un arco hasta la construcción póstuma que lo culmina, también en la forma de la impotencia. Siguiendo la lectura que Giorgio Agamben realiza de dicha noción en Aristóteles entendiendo por ella la capacidad de privación, de no pasar al acto, de suspenderse en la posibilidad y resistir a la realización totalizadora de una forma determinada, esta lectura encuentra que Invenciones del recuerdo se mueve en zonas de potencias donde se disuelve el Sujeto que vendría a narrar una vida pasada - autobiografía — para dar cuenta de una composición imprevista con lo «lo sido» (Heidegger ) y donde la «invención», el «instinto», la «infancia», lo póstumo y la edición la afectan.

Para desarrollar estas hipótesis dividiremos el trabajo en siete apartados que analizan y descomponen la noción de «prenatal» en matices que Ocampo presenta hasta legar a su relación con la naturaleza póstuma de esta escritura.

Palabras clave: prenatal / infancia / instinto / invención /edición

\section{Prenatal and posthumous: Powerless writings in Inventions of remembrance of Silvina Ocampo}

Abstract

Inventions of remembrance, of Silvina Ocampo, is part of the author's posthumous corpus. In 2006, Sudamericana published this work under the care of Ernesto Montequin, which has been considered an autobiographical text.

This paper intends to point out that Inventions of remembrance is not an autobiographical work but a text that exposes scriptural impotence from the expression «prenatal» that opens an arc to the posthumous construction that also culminates in the form of impotence. Following the reading that Giorgio Agamben makes of this notion in Aristotle as the capacity of deprivation, of not moving into the act, of suspending oneself in possibility and resisting the totalizing realization of a certain way, this reading finds that Inventions of remembrance moves in zones of potency where the Subject who would

Recibido: 13/3/2020. Aceptado: 13/12/2020

Para citar este artículo: Magallanes, R. (2021). Prenatal y póstumo: Escrituras impotentes en Invenciones del recuerdo de Silvina Ocampo. El taco en la brea, (13) (diciembre-mayo). Santa Fe, Argentina: UNL. eoo27

DOI: 10.14409/tb.v1i13.10216 
come to narrate a past life — autobiography_ dissolves to account for an unforeseen composition with «what has been» (Heidegger) and where «invention», «instinct», «childhood», the posthumous and the edition affect it.

To develop these hypotheses, we will divide the work into seven sections that analyze and decompose the notion of "prenatal» into nuances that Ocampo presents until he bequeaths his relationship with the posthumous nature of this writing.

Key words: prenatal / infancy / instinct / invention / edition

En Silvina no se puede separar la memoria de la imaginación, es casi un manifiesto,

Invenciones del recuerdo es eso.

Ernesto Montequin. Conversación.

\section{Introducción'}

La editorial Sudamericana comenzó a publicar, desde el año 2006, en ediciones al cuidado de Ernesto Montequin, diversos originales inéditos que Silvina Ocampo escribió entre 1936 y 1989. Es decir, a lo largo de los años en los cuales compuso su obra editada en vida. Este corpus póstumo está integrado hasta hoy por Las repeticiones y otros relatos inéditos (2006), escritos entre 1936 y 1989; Invenciones del recuerdo (2006), que Ocampo fue componiendo de manera fragmentaria entre 1960 y 1987; La torre sin fin (2007 en su edición póstuma aunque fue editada en vida de la autora en España), una novela corta para niños en la que la autora trabajó desde 1955 hasta 1984; Ejércitos de la oscuridad (2008), colección de fragmentos, aforismos, epigramas, argumentos, recuerdos que van desde 1950 hasta 1987, en forma intermitente; La promesa (2011), novela en la que trabajó Ocampo desde los años sesenta hasta 1989; y El dibujo del tiempo. Recuerdos, prólogos, entrevistas (2014) que atraviesa los años 1936 hasta 1989, compuesto de textos editados en vida e inéditos. En próximas publicaciones se conocerán poemas y obras de teatro (Montequin, 2021:s/p).

Como puede notarse a primera vista, se trata de un corpus heterogéneo y que supone procesos de escritura de larga duración. Es importante señalar, además, que en cada caso las intervenciones-composiciones editoriales son significativas. En Las repeticiones y otros relatos inéditos, por señalar un ejemplo que resuena en los demás volúmenes, Montequin reúne una serie de narraciones encontradas entre un material que describe como «cantidad considerable de relatos inconclusos o incompletos, de borradores descartados u olvidados, de fragmentos narrativos de diversa índole» (2006:7) como también escritos en disímiles papeles, libretas, colores, letras. Hacia el final de cada uno de los libros póstumos, el editor es meticuloso y detallado en la descripción de los originales, mostrando así la complejidad de reescrituras y la abundancia de matices de esos materiales, cuya cantidad y diversidad destacó nuevamente en una conversación que mantuvo recientemente referida a su trabajo con dichos manuscritos (2021:s/p).

Las obras póstumas de Silvina Ocampo, si atendemos a estas operaciones, se nos aparecen como construcciones editoriales realizadas a partir de una conversación escrituraria que Montequin establece con los manuscritos, fragmentos de textos, poemas y prosas inéditos de la autora. El editor, entonces, selecciona, entre una gran cantidad de material de archivo, escritos dispersos, algunos más que otros, que detalla en las «Notas al texto» a cada volumen en su materialidad, sus múltiples versiones, sus comparaciones con obras publicadas en vida. 
Atendiendo a esta conversación escrituraria entre autora y editor-curador este trabajo propone una lectura de Invenciones del recuerdo enfocada, por un lado, en una noción inestable, fluctuante y a la vez central en el texto como es la de «prenatal» y, por otro lado, en la relación entre lo prenatal y lo póstumo.

\section{Prenatal}

Silvina Ocampo define los apuntes que se transformarán en Invenciones del recuerdo, en una entrevista de 1979, como «historia prenatal» (2014:267). La manera de indicar la índole de esta escritura, categórica y al mismo tiempo de una ambigüedad sugestiva, cobra mayor relevancia cuando la reunimos con el título mismo. Nos encontramos, así, en medio de una articulación paradojal: ¿cómo hay historia en algo que aún no existe?; ¿qué tipo de historia se pone en juego?; ¿o en qué forma existe y hace historia aquello que aún no habita el mundo, que no ha comenzado a ser y recuerda?; ¿hay un sujeto de esos recuerdos que inventan?; ¿qué implicancias conlleva un recuerdo inventivo y no rememorativo?

Un modo de pensar estas preguntas es explorar Invenciones del recuerdo desde una perspectiva que suspenda momentáneamente la idea de Historia con mayúscula, de relato autobiográfico de un pasado de niñez, ${ }^{2}$ atender a lo que Ocampo dijo «Yo no tengo autobiografía. Tendría que inventarla» (2014:214) y que podría permitirnos a la vez que sostener la intensidad de esas paradojas también recorrerlas para experimentar y poder delinear sus impresiones. Entonces podríamos vislumbrar una escritura y un libro donde lo no vivido, lo no experimentado en el modo de la realización - aquello que Giorgio Agamben retoma de Aristóteles: la impotencia (o potencia de no) como resistencia de la potencia en sostenerse en su pura posibilidad y no pasar al acto, a una forma determinada y acabada — se traza prenatalmente.

La palabra elegida por Ocampo, «prenatal», operaría como una multiplicidad de sentidos resbaladizos cuya apertura prima o está en tensión constante con una acción que silencia la potencia de la escritura. Lo prenatal, entonces, parece improvisarse - utilizo este término para enfatizar la ausencia de plan, la no realización, ni finalización — en una escritura que expone su propia amorfia, que se mantiene en un «pre», y que si bien recuerda, lo hace en el modo de la invención; se trata de un recuerdo que no obra como conocimiento ni comunicación de un contenido en ese «monstruoso compromiso entre destino y memoria» en la que solo puede pensarse como «objeto de recuerdo (el retorno de lo idéntico)» (Agamben, 2002:34) sino que recuerda en la potencia del no - la impotencia- Recuerdo que, por otra parte, tiene lugar en una zona escrituraria que se esboza entre la materialidad textual, el archivo, la edición y el libro póstumo.

\section{Prenatal como invención}

El recuerdo se encuentra enlazado con lo prenatal en la paradoja que presenta Ocampo. Un modo de recorrer la singularidad de esta convivencia de incongruencias es detenerse en la operación que se lleva a cabo en la invención, que podríamos denominar contraontológica (Cassin, 2008). ${ }^{4}$ Porque Ocampo no puede relatar lo pasado vivido ya que:

\footnotetext{
El recuerdo está lleno de desmayos,

de pérdidas de conocimiento.

Se llega a un lugar sin haber partido
} 
de otro, sin llegar.

Se ama a una persona que uno no recuerda,

más que a una persona que uno recuerda.

Hay manos sin caras,

cuerpos sin palabras,

palabras sin cuerpos,

vestidos solos, jabones importantes como personas.

La gama de confusión en infinita. (Ocampo, 2006:37)

\section{Como también:}

Lo que falta en los recuerdos de infancia es la continuidad:

son como tarjetas postales,

$\sin$ fecha,

que cambiamos caprichosamente de lugar.

Algo se interrumpe y se corta para siempre. ${ }^{5}$ (2006:111)

Los desmayos, pérdidas de conocimiento, la infinita confusión, las tarjetas postales sin fecha que arbitrariamente se cambian de lugar sugieren poner en crisis tiempos, espacios, pasado y su comunicación gnoseológica límpida para abrir un «territorio previo que hace posible la irrupción intempestiva de lo imposible» (Derrida en Chun, 2019:13):

«¿Qué es una “invención”? ¿Qué hace? Viene a encontrar por primera vez» (Derrida, 1987:74), pregunta y responde Derrida en «Psyché, invenciones del otro», ensayo en el que aborda la cuestión de la invención para explicitar el vínculo existente entre la herencia y la posibilidad del acontecimiento. Para el pensador franco-magrebí no hay invención sin una inserción en lo establecido, pero, a su vez, para que haya invención debe existir la posibilidad de interrumpir las normas vigentes. Invención imposible, invención de lo imposible, tal es la apuesta que tanto en el campo de la estética como en el político nos invita a retomar. ${ }^{6}$ (Chun, 2019:13)

Si esto es posible (como se pregunta Derrida «¿Sucede alguna vez? De este evento no estamos nunca seguros» —en Chun, 2019:19-), quizás lo sea cuando Invenciones del recuerdo improvisa un «sido», en sentido heideggeriano: aquello pasado no irrevocable sino que insiste activo y con lo que se cultiva una conversación, ${ }^{7}$ tal vez infinita, un sido prenatal de invención. ${ }^{8}$

La primera parte del texto nos dice que existen «imágenes» que están «grabadas» «dentro de aquel gris, prenatal corazón»:

En la ciudad natal, que lleva un nombre tan contradictorio, en la calle Viamonte, frente a una iglesia (con rejas, un monasterio, una palmera, un río, un almacén) un perro ladró, parecía en el campo 


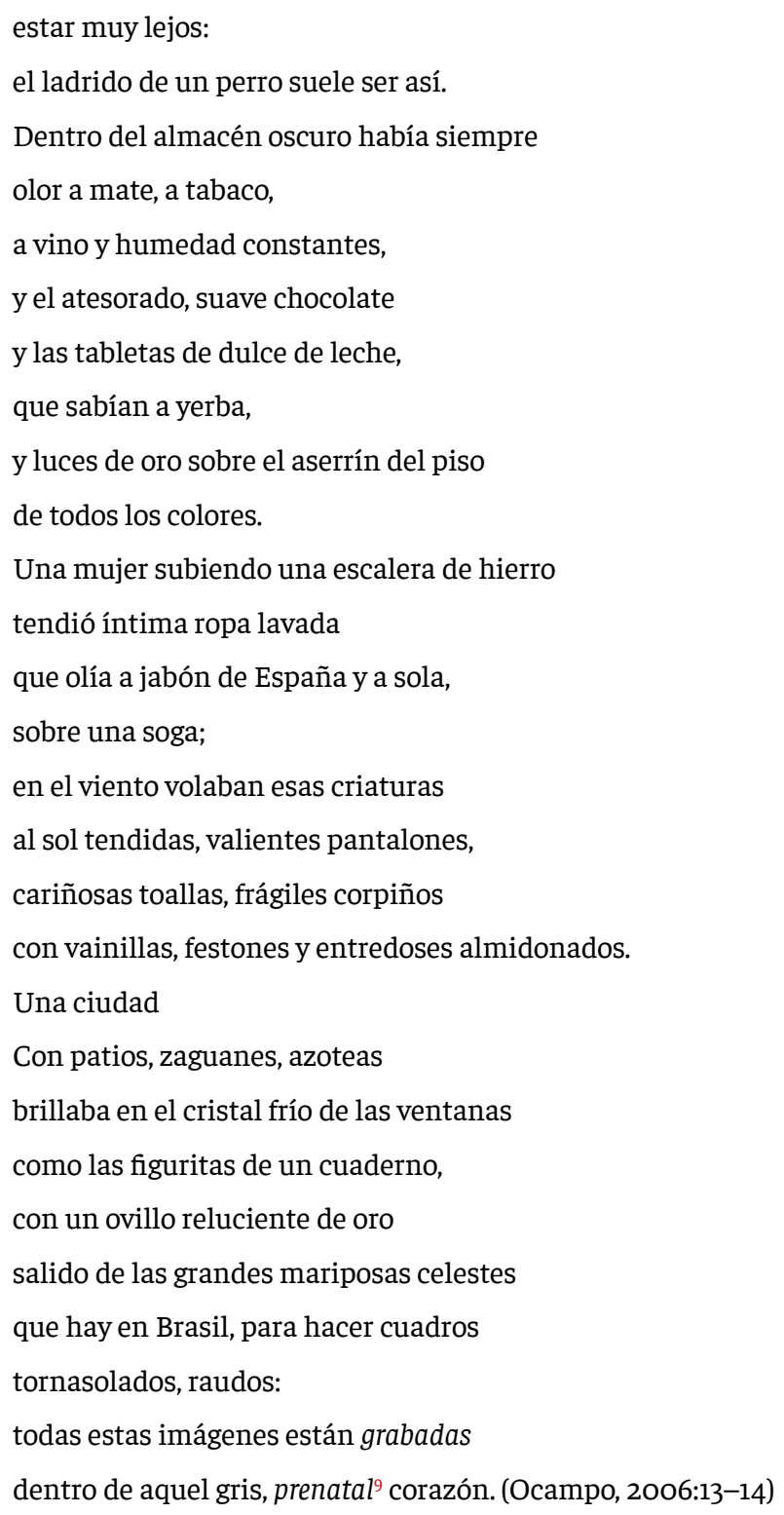

Lo prenatal es presentado como un modo de ser de un corazón. "Aquel», que también es gris, donde hay grabaciones, impresiones. No se trata, entonces, de un vacío, un origen. Lo prenatal ya está marcado, y existe en un turbio «aquel», en un intermedio y vago gris — no en el rojo, según la simbología vinculada al corazón - en el cuerpo. Se dibuja, así, un territorio de imágenes que inventa, con confusión, desmayos, desconocimiento, una experiencia «sida» cuyas grabaciones, sin embargo, no responden «al cálculo de la anticipación, el cual siempre nos condena a la eterna repetición de lo mismo», como dice Derrida, sino que se lanza al juego impotente de una temporalidad «con cara de mago» (Ocampo, 2006:177).

«Aquel» corazón tampoco parece tener sujeto. Su índole de núcleo se desarma, sus grabaciones ofician como latidos escriturarios, relámpagos de acontecimientos insustanciales; Invenciones del recuerdo puede leerse como otro modo de ser de aquel corazón, que no se detiene en su aventura de no vivir.

«Huye, ha quedado» (Ocampo, 2006:11) es una de las frases que despunta esta escritura prenatal. Irse, escapar hacia el mismo lugar, permanecer, luego de ese movimiento de ímpetu 
acentúa el lugar paradojal del texto. En este gesto, lo prenatal parece mostrarse como un reino de Invenciones del recuerdo: «Reinar no significa cumplir con todo. Significa que lo incumplido es aquello que permanece» (Agamben, 2005:43). Este huir y quedar trata de salvar las cosas olvidadas, ${ }^{10}$ en tanto perdidas, incumplidas, es decir, trata de salvar su propio olvido y configurar trozos, escombros que remueven y abren lugar a otros derrumbes que no evocan una totalidad perdida, socavada que implicaría el recuerdo de lo mismo, sino que poetizan los incumplimientos, las piezas, parcelas, pizcas, cortes, separaciones. ${ }^{11}$

Ese poetizar actúa en las invenciones, en el estado de previo sostenido, de potencia y de reino, que Ocampo llama «prenatal». Podemos vislumbrarlo en el modo de descripción de los objetos, colocados en atmósferas que los descentran de sus típicos horizontes de existencia y en múltiples episodios «sueltos».

La invención, así, «deja venir»: objetos deseados y adorados que usurpan una naturaleza impropia, diferente —una mecedora pequeña, un vestido—, partes del cuerpo humano que se manifiestan de diversas formas, desprendidos de la totalidad fisiológica que debería unificarlos; o dos tías que podrían oficiar de portales ${ }^{12}$ para estas experiencias: en uno de sus cuartos hay una cosa que le gusta a la escritora, que es «el único destello de luz que había en ese dormitorio» (Ocampo, 2006:23) una mecedora diminuta "para las proporciones de un enano sobrenatural» (22), que se desplazaba por los rincones «sin que supiera para qué, por quién ni para quién» (22).

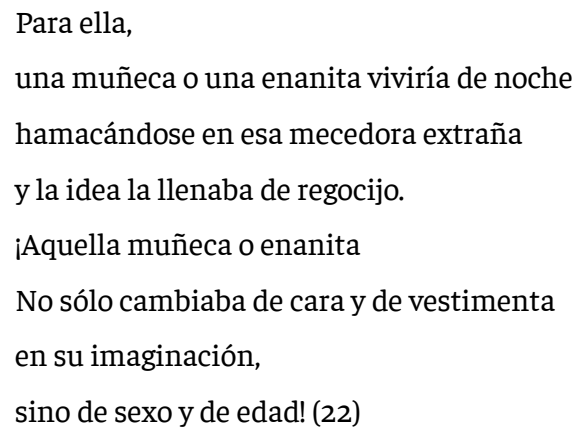

Sin que se lo dijeran — no se animaba a preguntar — un día supo que la mecedora era para hamacar los pies: «los íntimos, los independientes pies» (23), y así se estableció una relación de amistad entre sus pies y los de sus tías, separadas del resto del cuerpo. Con su «vaivén gracioso», descubrió en ellos «dos mellizos rítmicos y mudos», que no la juzgaban, que no veían en su infancia, como sí lo hacían sus tías, un ser no verdadero, imposible de querer (24).

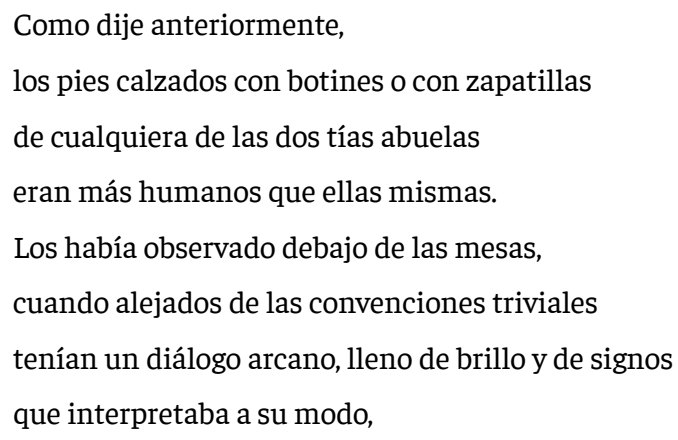


cuando nerviosos se agitaban diciendo no o diciendo sí,

o tal vez, o puede ser o nunca. (25)

En un apartado - el armado del texto configura espacios en blanco que intensifican la importancia de la "parte», de lo «fragmentario»— aparecen las manos. Sus manos desprendidas que, como los pies, se revelan, emergen desgajadas de un todo, pero que, sin embargo, ese todo no las incluye ni sostiene, ellas en sí mismas son, llenas de percepciones, actos encontrados y diversos, sabidurías, presentimientos:

Sus manos enguantadas como las sillas de la ciudad

en verano, con forros blancos, son ajenas, aparentemente.

Conocen, instruyen, averiguan, enjabonan, dan, reciben,

se esclavizan, se humillan

furtivas

tocan lo que aman,

engañan, traicionan, roban,

hieren, cortan, destruyen,

atesoran, curan, vigilan,

se resignan, se persignan,

se pervierten, se esconden.

Adivinan el color de un tejido

en la oscuridad,

de un gusto en la forma,

de un sentimiento en la temperatura.

Buscan, pierden, descubren

el teclado de un piano,

la forma de un abanico lejos de la cara,

lejos del cuerpo

como si tuvieran mil ojos

y corazones.

Mueren de amor, esperan

besan, escuchan, tienen orejitas en sus palmas,

dicen adiós como pañuelos;

atesoran anillos

caídos de las cortinas,

se asombran, se arrodillan

imitando a las personas mayores;

palpan las llaves

que preservan de la mala suerte.

Reemplazan la voz. (Ocampo, 2006:28)

Las manos vuelven a surgir con el profesor de dibujo de sus hermanas. Ella los espiaba, mientras trabajan, debajo de la mesa juntando papeles tirados y comiendo pedacitos de goma de 
borrar. Desde ese lugar, el de los papeles descartados, recuperados en su olvido y desecho, y de la borradura que se come construye el recorte de una mano, única, solitaria, que vale por sí, de naturaleza dibujada:

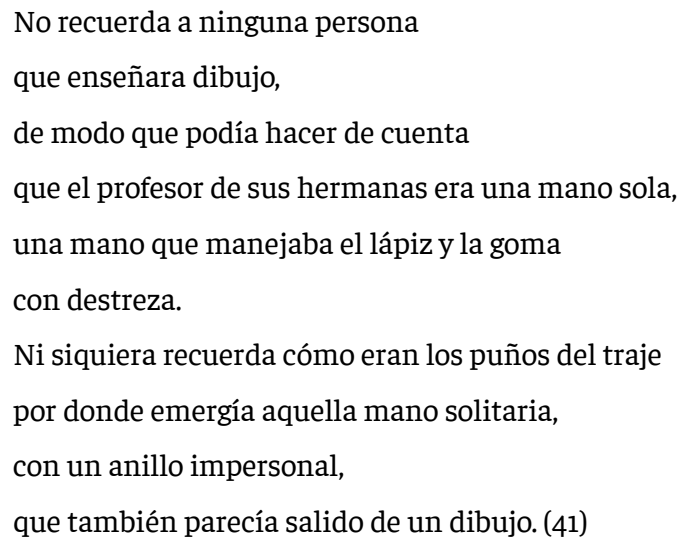

En último lugar, otra mano, junto a una cabeza y una garganta, se asoma desde el aljibe, donde habitan los tres, para recibir «las piedras prohibidas que arrojaba» (Ocampo, 2006:70). Ella había aprendido otra lengua, o una no-lengua: el idioma del aljibe y decía «Vení» y subían «con el chirrido de la cadena en la roldana; / la cabeza,/ la garganta y la mano/fraccionadas/ adentro del balde/ para que las tragara,/ a pequeños sorbos,/ en un vasito de plata/ que por dentro era dorado» (71).

Otra forma de invención prenatal aparece cuando un objeto se deja ver en su novedad, en su potencia que pulveriza la forma instituida, como el vestido violeta, de seda. Un vestido complicado. Fuera del armario, apoyado en una silla o parado en la percha parecía una persona. Ella esperaba quedar a solas con él, «Esperaba que le hablara. Miento. No./ No esperaba que le hablara./ Nada se dice hablando/ cuando hay tanta ternura» (2006:79-80). Lo que en realidad esperaba era que «esa luz de amatista/ estampara permanentemente/ lo que la ausencia pretendía robar» (80). Esperaba una impresión, una marca de lo que no está, no es; ni puede, por lo tanto, ser conocido «del todo»: «Siempre en alguno de sus pliegues/ ocultaba un bolsillito, una tablita/ un fruncido que no había advertido» (80), pero que como tal requiere ser rescatado, pero que a la vez solo puede lograrlo en el rodeo de la invención, «ésa era su magia» (80). Hasta que vinieron a buscarlo para llevarlo a la tintorería. Entonces llevó el vestido debajo de su cama y se acostó encima. Los «verdugos» entraron a buscarlo, en el armario, hurgaron:

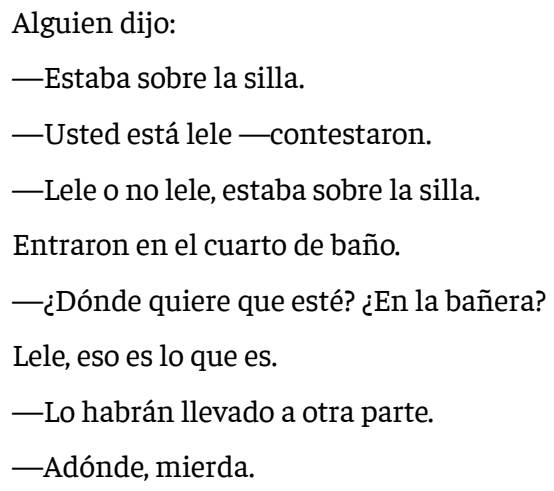


-Boca sucia de culo.

-Cabeza hueca de calabaza.

—Cucaracha sin dientes. Oruga babosa. (81)

Durante esa escena donde se «dicen cosas tan locas que parecen cómicas», y parece resurgir lo que Biancotto señala como el nonsense en Silvina Ocampo: «un modo de ver el mundo y un modo de estar en la escritura» (2015:44) se da un ocultamiento que des-oculta en el modo de una «docta ciega», o de una iniciada en los misterios que procede, como los escritores, en la oscuridad (Agamben, 2016:15):

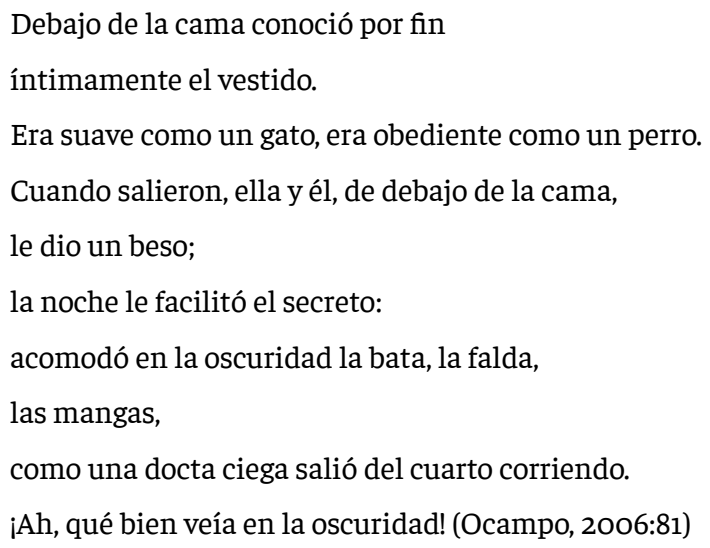

Finalmente, aparece la cara. Una cara no solo desunida de un cuerpo sustancial como horizonte de su aparición, sino una cara plenamente dibujada, impresa. Que, además, insiste en Invenciones del recuerdo con mayor fuerza que otros de los elementos mencionados. La primera aparición es muy significativa en tanto el dibujo de la cara se junta con todas las letras (2006:56), como si retomando un prenatal territorio de la escritura como dibujo ${ }^{13}$ Ocampo presentara a la vez el propio texto como un rostro que se inventa mientras se dibuja, una figura que parece coser la tela donde cada pieza desmontada de «lo sido» podría ser ubicada en una exhibición arqueológica del reino de lo inolvidable.

Este procedimiento también recuerda aquel que realizaba Emmanuel Levinas cuando pensaba al Otro como Rostro infinito. El rostro como el Otro in-sintetizable, no relativo a un contexto, no contenido por ningún sistema o pensamiento, sino como exterioridad radical. Un rostro que se presenta en un encuentro ético anterior al tiempo, al ser, al conocimiento, a la ontología. Una experiencia inmemorial in-sincronizable en la que se abre una brecha sin fondo común, sin totalidad que subsuma y defina en una síntesis: es un Decir «heme aquí» y la substitución del Otro en mí (Levinas, 1995, 1997). La cara de Ocampo, como el rostro infinito de Levinas, expone el costado inventivo de una escritura-dibujo en potencia como aquel Decir, previa a toda mismidad, a toda reducción en la actualización en una forma, indeterminada, pura apertura a lo Otro.

Solía dibujar caras

con lápices de colores o con tiza

en la glorieta,

en la pared de las casas, 
en la tierra con una rama,

en un vidrio empañado con un dedo,

en un jabón con las uñas.

Sabía escribir la letra A mayúscula porque parecía una casita,

la $s$ porque parecía un cisne,

la o porque parecía un huevo,

la $i$ porque parecía un soldadito.

Pero dibujar una cara encerraba para ella

todas las letras. (Ocampo, 2006:56)

Esa cara parece mostrarnos el infinito de la escritura, la imposibilidad de su cerramiento, de su limitación. Porque, además, ella volvía cada vez que quería dibujar otra cosa. «Trataba de dibujar un tigre/ dibujaba la misma cara de siempre» (2006:167). Quiso dibujar botes en el río, iglesias, la plaza, el carrito de un vendedor "pero su mano trazó lentamente/la cara de siempre» (168), «pero siempre era la misma cara./ Tenía el pelo lacio,/ los ojos alargados» (91). La dibujaba con los ojos cerrados. Podía ser mujer. Podía ser varón. Comenzó a dibujarla con tiza debajo de la glorieta. La amonestaron porque hacía garabatos en un piso bonito (133).

La cara se puso muy seria,

el cuello se alargó,

para dulcificarlo le agregó collares,

un sombrero.

Le dijeron:

—Los hombres no usan collares.

—Sombreros, sí — dijo.

—¿Pero es mujer u hombre? —le preguntaron.

—Un poquito mujer, un poquito hombre — contestó.

Pero sintió que nadie admiraba su dibujo.

Se puso triste porque había malogrado el álbum.

Lo llenó de perfiles, esta vez sin restricciones.

—¿Éste es el cura? - le preguntaron de uno de sus perfiles,

más atrevido que los otros.

La ofensa le dolió tanto

que resolvió llenar las hojas de números,

pero detrás de los números aparecía siempre el perfil,

ese perfil que a veces tenía dos ojos

o la mitad de la cara de frente o la boca entera

con las comisuras bien marcadas. (169)

Hacia el final del texto, la cara aparece en una última manifestación: «la llevaba un joven» (176). La cara dibujada la llamaba, quería ser mirada, le decía señorita, y ella fue dejando de ver. Primero el jardín. Luego los árboles, el portón, sus rodillas. Hasta que la cara, el joven le dijeron: «一Míreme, señorita» (176). Y el texto y su invención se interrumpen. 


\section{Prenatal como instinto}

Invenciones del recuerdo no es un poema, dice Ocampo en una entrevista realizada para Clarín con Luis Mazas, el 22 de noviembre de 1979, es: «una historia que denomino prenatal, escrita casi en verso, pero que no es un poema. Se trata de un libro donde predomina mi instinto. ${ }^{14}$ Era verso y lo destruí. Lo hice en prosa también lo destruí» (2014:67).

¿Cómo deviene una escritura instintiva prenatal? Según el texto de la entrevista adviene luego de destrucciones de modos establecidos de escritura: poema/prosa. «Destrucción (Destruktion) —afirma Heidegger - no significa aniquilar, sino desmontar, escombrar y poner-a-un-lado (auf-die-Seite-stellen)» (1969:44). En este caso, si seguimos esta idea, la destrucción operaría en las formas instituidas del poema y la prosa. El término instinto, nos indica Ocampo, actúa como otro matiz de la inagotable noción de «prenatal». Un instinto (cuyo etimología latina es «impulso», «inspiración») se manifiesta aquí como algo lejano y contrapuesto a una racionalidad, como también a un plan previo deliberado de un sujeto, enmarcado en un género preestablecido, y, asimismo, opuesto a los recuerdos conscientes.

Este instinto al que se refiere Ocampo tanto en el contexto de la cita tomada de la entrevista como pensándolo operando en Invenciones del recuerdo se equipara con otras disposiciones ya leídas: son instinto y corazón las zonas donde predomina lo prenatal, las elegidas por la autora entre otras que pudo haber consignado como «mente» o «pensamiento», vinculados en general al acto de lo reflexivo, a la actividad intelectual de un sujeto. Sin embargo, como destruyó el poema y la prosa también, desechó aquellas instancias y eligió símbolos del sentir, de la afectividad que, por otro lado, enfatizan lo impulsivo, la intensidad que produce la escritura. De hecho esa poética libre que el libro compone parece dejarse llevar con lo «grabado» en aquel prenatal corazón donde predomina el instinto, sin tener razón de ello, sin un saber que el tiempo cronológico y pautado le haya traído a la memoria: «La cronología no existe en el tiempo del recuerdo» (Ocampo, 2006:28).15

Por un lado, el acto de destrucción de Ocampo que está en medio o forma parte de la escritura de Invenciones del recuerdo si bien dialoga con la concepción heideggeriana de «destrucción» también lo hace con otra inspirada en ella. Me refiero a la «deconstrucción» de Derrida. Dice el autor y analiza Chun:

La deconstrucción es inventiva o no es, no se contenta con procedimientos metódicos, se abre un camino, marcha y marca; su escritura no es solamente performativa, ella produce reglas —otras convenciones - para nuevas performatividades y no se instala nunca en la seguridad teórica de una oposición simple entre performativo y constatativo. Su marcha compromete una afirmación, que se vincula al venir del acontecimiento, del advenimiento y de la invención. Pero no puede hacerlo sino deconstruyendo una estructura conceptual e institucional de la invención; como si fuese necesario, más allá de cierto estatuto tradicional de la invención, reinventar el futuro porvenir. (Chun, 2019:74)

La invención excede al cálculo, al saber, al dominio de un sujeto, ya que si no lo hiciera se reduciría a la mecánica aplicación de un programa previo. Una invención reducida a lo posible, entonces, nunca es tal. Inventar implica un in-venire, un dejar venir a la alteridad, extraño extranjero que pone en crisis nuestra morada. Pero, por supuesto, hay una herencia, un espacio donde hacer lugar a la llegada de ese otro, territorio previo que hace posible la irrupción intempestiva de lo imposible. Esta tarea es la deconstrucción, invención que acoge a la invención, es decir, que expresa una hospitalidad 
incondicional ante la llegada de cualquier/absolutamente otro. Aquí se impone la necesidad de revisar el tan gastado concepto «deconstrucción», el cual no implica un movimiento dialéctico entre una instancia constructiva y una destructiva, sino el reconocimiento del abismo sobre el que se funda toda norma. (13)

Por otro lado, al escribir el término «instinto» Ocampo parece dirigirnos hacia una problemática muy suya que es la de la animalidad. Julieta Yelin ha explorado con detenimiento esta cuestión desde diferentes lecturas. Una de ellas centrada en dos cuentos de Ocampo, «Isis», perteneciente a Las invitadas (1961) y «Azabache», a La furia (1959). Yelin utiliza tres expresiones para interpretar la relación entre ellos ${ }^{16}$ que son «disolución subjetiva», «animalización» $\mathrm{y}$ «puerta de pasaje a la animalidad». Creo que esos criterios permiten pensar el «instinto» del que habla Ocampo, como sinónimos suyos.

Asimismo, señala Yelin siguiendo a Derrida, que los inicios de la relación de lo humano con lo animal tienen por base «la paradoja de un "antes" o una prehistoria» que no puede ser pensada, es acrónica, exterior al tiempo «o más bien eternamente contemporánea»; esto resuena fuertemente en la noción de prenatal. Así, para salvar esta paradoja «se estableció una anterioridad hipotética del animal, que permite, a partir de la causalidad, situar un punto de origen». Dice Derrida «El hombre está "después" del animal, en los dos sentidos del término. Lo sigue. Este "después" de la secuencia, de la consecuencia o de la persecución no está en el tiempo, no es temporal: es la génesis misma del tiempo» (Derrida en Yelin, 2015:100).

Por otra parte, y en el mismo sentido, el nacimiento instintivo que Ocampo le atribuye a la escritura de Invenciones del recuerdo igualmente puede hacer eco con el término «vocación» tal como lo piensa Leonardo Sanhueza:

no como una ética ni una fuerza moral con que las personas acometen sus ocupaciones, sino simplemente al «llamado» de un escritor y a la historia de esa metamorfosis, descrita a menudo como si fuera un big-bang o, al menos, la consumación de un proceso inevitable, casi de orden biológico. (2018:14-15)

La apelación a lo biológico tiene un costado de lectura que apunta a la relación entre bios, logos y zoe. Bios remite a vida pero no a la vida animal que se expresa en el término zoe. Zoe es una vida sin logos, a diferencia de bios, que lo implica. ${ }^{17}$

Así, el instinto ocampeano, si lo ponemos en conversación con estas lecturas, podría entreverse en una disputa que tensa tanto las dos formas de lo viviente como al logos —entendido como ser/pensamiento/palabra/escritura— - pero que, sin embargo, se inclina por una situación zoográfica. La escritura de una vida previa al logos, a lo subjetivo la escritura de un «yo incierto (...) anterior a Silvina Ocampo» (Biancotto, 2009:5) se torna congruente con lo que Yelin denomina «disolución subjetiva», «animalización»; y con el hipotético «antes», o «prehistoria» de lo animal en relación con lo humano. Porque, además, ambos, antes y después, no pueden ser pensados, ya que esa operación implica el tiempo cronológico, del que, como recuerda Derrida, son expulsados como la subjetividad y el lenguaje. ${ }^{18}$ Esta disolución subjetiva nos acerca a lo que Ocampo llama instinto como otra faceta de lo prenatal. La animalización, junto a aquella disolución, queda inscripta en muchas de sus enumeraciones: 
sé que soy como un gusano/ que valgo menos que una mosca/ que come bosta o inmundicias. (Ocampo, 2006:116)

salió de sí misma como un caracol. ${ }^{19}(158)$

Otros recuentos se refieren por ejemplo a la piel de tigre y de oso blanco con las cabezas embalsamadas sobre las que se sentaba en la casa de sus tías, y limpiaba los dientes de esas fieras, les daba de comer y beber, y la retaban (128); las tantas moscas, mariposas, ranas, tigres, jaguares (138); el perro Cariño (151-152); las vacas, chimangos, más ovejas y caballos (158); «gusanos repugnantes/ que son como dragones/ en miniatura» (170); el benteveo cruel (174); las sirenas, leones, canarios locos, gallinas en cajas de vidrio, nidos de horneros (12); nidos de abejas (79); perros lanudos (17); más canarios y gallinas (118-119), caballos (33); pulgas muertas en un vaso para dientes (25); más nidos y pájaros y crines de caballos criollos al viento (35); Blanquita, una cabra (54, 85, 96-99), mosquitos (92); peces caídos (94); el petizo para el que atesoraba azúcar (97); un perro recién nacido y la confusión que la excitó, la lleno de culpa mortal por un episodio que se transformó en pecado, al que la tentó Chango:

¿Qué vio por agujero de la cerradura

cuando le mostró que existía el infierno?

(...)

«Te voy mostrar algo»

obedecer al pecado, mirar

ver algo que parece un animal acechante,

un animal ciego,

sin orejas, ni ojos. (106)

Y luego:

- Tenés que mirar por la cerradura de la puerta muñeca.

Sola, en aquel cuarto,

tuvo que mirar.

(...)

se acercó a la cerradura y miró.

(...)

Entre los pliegues blancos de una camisa, tal vez, un perro recién nacido, tal vez,

(...)

Algo que no era un perro recién nacido asomaba por entre los pliegues de su camisa, adentro del pantalón entreabierto.

No podía ser un perro.

Era un objeto que formaba parte

del cuerpo del hombre. (134-135) 


\section{Prenatal como infancia}

Una definición ya canónica de Agamben dice de la infancia:

Una experiencia originaria, lejos de ser algo subjetivo, no podría ser entonces sino aquello que en el hombre está antes del sujeto, es decir, antes del lenguaje: una experiencia «muda» en el sentido literal del término, una in-fancia del hombre cuyo límite justamente el lenguaje debería señalar. (2007:64)

Invenciones del recuerdo es esa escritura de señalamiento, un garabato, el de la cara dibujada en tiza en el piso bonito bajo la glorieta, un garabato que no busca sentidos rígidos ni definitivas memorias, sino potenciar esa experiencia acrónica de recuerdos inventados.

A esos garabatos de la insipiencia de algo por venir Gilles Deleuze los denomina balbuceos. Y podemos pensar en ellos para abordar la lectura de este texto peculiar. Dice Deleuze del balbuceo:

es lo que hace que la lengua crezca por en medio, como si fuera hierba, lo que la convierte en rizoma en vez de árbol, lo que pone la lengua en perpetuo desequilibrio: Mal vu mal dit [mal visto mal dicho] (contenido y expresión). Decir las cosas tan bien dichas nunca ha sido lo propio ni la tarea de los grandes escritores. (1996:155)

El lector sólo verá desfilar los medios inadecuados: fragmentos, alusiones, esfuerzos, búsquedas, que no trate de encontrar una frase bien relamida o una imagen perfectamente coherente, lo que se imprimirá en las páginas será un discurso turbado, un balbuceo. (1996:158-9)

\section{Leemos en Invenciones del recuerdo:}

Le enseñaron a hablar

de acuerdo con el Léxicon para bebés

que acaba de aparecer.

Cuando le dieron el libro, preguntó:

-¿Para qué?

-Para lelo - le contestaron.

Después de los u u u u u us que pronunció, después de las a a a a ah ah ah, después de los oh oh oh oh oh, de los gue gue gue,

de los re re re que pronunciaba correctamente comenzó a desvariar: dijo sopa, corrigieron: papa; dijo coche, corrigieron: tutú; dijo zapatos, corrigieron: pepés (...) -Nunca va a hablar como la gente esta chica —declaró la dueña del Lexicon para bebés. (Ocampo, 2006:14-15) 
Según la definición de Phillippe Lejeune ${ }^{20}$ la autobiografía supone, por un lado, la identificación del autor, el narrador y el personaje, y por otro, la narración de su propia vida, propósito e intención que quedan establecidos con la firma del autor en la obra y que así son interpretados por el lector como consecuencia del pacto autobiográfico (1974:14). Como señala Biancotto, nada de eso se encuentra en Invenciones del recuerdo, que ya desde su título paradojal nos anuncia que el camino de lectura tiene que ser atento a sus desvaríos, juegos, misterios que nunca anclan en un discurso fijado del pasado. Que nunca hacen pie. La misma Ocampo nos dice: «El recuerdo está lleno de desmayos,/ de pérdidas de conocimiento/ (...) La gama de confusión en infinita» (2006:37). Incluso la voz que escribe en tercera persona pasa a la primera y viceversa. ${ }^{21}$ No hay pacto autobiográfico, no solo porque no se está narrando la historia de una vida sino porque la propia Ocampo deja claro que el modo del texto reviste otros relieves mucho más complejos y confusos. No es su intención despejar esas confusiones ni perplejidades, porque son propias de ese estado incógnito, insondable de la infancia como modo de lo prenatal; antes bien, lo que se está proponiendo es acompañar e inventar en la escritura y lectura esa experiencia.

En la entrevista mencionada anteriormente realizada con Luis Mazas, Ocampo dice:

Siempre recuerdo ese verso que dice ¡Oh infancia! ¡Oh amiga! Y lo que importa en él es lo que no dice. Nuestra infancia es ciertamente nuestra amiga, pero nosotros no fuimos amigos de nuestra infancia porque entonces no existíamos como somos ahora. Aquel ser desvalido que fuimos a veces se conmueve porque nadie pudo comprenderlo del todo salvo nosotros, que todavía no estábamos a su lado. (en Montequin, 2006:181)

Ocampo nota claramente ese territorio donde no hay un sujeto que pueda recordarlo porque se encuentra fuera de ese tiempo donde la subjetividad, la historia, el lenguaje se constituyen, por esto, es justamente esa rareza de experiencias inventivas de lo originario lo que les da lugar. ${ }^{22}$

Un fragmento del texto, que además muestra la experimentación con el cambio de persona, dice: «Cuando recuerdo su infancia/yo la asocio a esos árboles oscuros/porque son más misteriosos que los otros;/ árboles cuyo follaje a lo lejos/ parece el humo de una explosión/ o las crines de caballos criollos al viento» (2006:35). Las asociaciones ponen en evidencia a la infancia como ausencia de un lenguaje, de un sujeto. La infancia acontece en un misterio, una explosión -un «big-bang»—, un humo, una neblina que a la vez opaca las formas, se disipa con el viento de los abismos de la otredad.

\section{Prenatal como pre y pos. Lo póstumo y la edición}

Las obras póstumas de Silvina Ocampo pueden ser exploradas como zonas de articulación de dos escrituras, como se señaló en la Introducción del presente trabajo, la escritura inédita de Ocampo y también la editorial de Montequin. Los procedimientos editoriales que realiza - seleccionando textos entre una gran cantidad de material de archivo, un conjunto de muy variada procedencia y formato, armando y componiendo libros - es determinante y forma parte de lo póstumo mismo.

Montequin parece continuar con la idea planteada por Philippe Artiéres según la cual «Los escritos solo existen desde el momento en que se los puede describir con suficiente precisión" (Artiéres, 2019:10). Esta práctica descriptiva, que dialoga con otras categorías que abordan la 
materialidad escrituraria como «expediente genético», «tachaduras», «añadiduras» (Contat y Ferrer en Artiéres, 2019:12); "papeles», "proceso de escritura» (Claire Bustarret en Artiéres, 2019:12), «escenario de escritura», «objetos de escritura» (Daniel Fabre en Artiéres, 2019:13), por citar algunas de ellas, están muy presentes en el trabajo que Montequin, con pormenor y cierta fascinación, se propone al describir el «archivo» póstumo de Invenciones del recuerdo en sus «Notas la texto». Para dar apenas un ejemplo, escribe:

en el conjunto de originales se distinguen tres etapas bien definidas a partir de las cuales puede reconstruirse el intrincado proceso de escritura.

La primera etapa tiene como punto de partida un breve poema en verso libre, cuyos primeros borradores de puño y letra de la autora, titulados «Exigua autobiografía» 0 «Poema autobiográfico», fueron probablemente escritos a fines de la década de 1950. Sucesivas reescrituras irán modificándolo y ampliándolo a lo largo de las dos décadas siguientes, bajo distintos títulos: «Poema prenatal»; «Canto prenatal»; «Con alma ajena»; «Memoria prenatal»; «Strobilos»; «De memoria»; «El trompo y el látigo». Esta última versión, de 78 carillas mecanografiadas, es la más extensa de todas. La titulada «Con alma ajena» (34 carillas mecanografiadas) dio nombre a una versión temprana de Amarillo celeste (1972) que también incluía un grupo de poemas que aún permanecen inéditos.

A una segunda etapa corresponden dos textos en prosa, escritos entre 1959 y 1960, inicialmente titulados "Carta» $\mathrm{y}$ «Presciencias», de los cuales se conservan los borradores autógrafos y una apreciable cantidad de copias mecanografiadas profusamente corregidas a mano por la autora. El hecho de que estén narrados en segunda persona del singular, al igual que «El pecado mortal» $\mathrm{y}$ «Anillo de humo», dos relatos publicados en Las invitadas (1961), permite conjeturar que todos integraban una misma serie de «cuentos autobiográficos». En su versión final ambos textos en prosa forman un original mecanografiado de 54 carillas, dividido en dos partes, numeradas «I» $\mathrm{y}$ «II», con correcciones y adiciones autógrafas, $\mathrm{y}$ encarpetados bajo el título de Invenciones del recuerdo.

Finalmente, en la tercera y última etapa, que puede datarse entre 1980 y 1987, confluyen los materiales de las dos instancias previas en un texto único en verso libre. Esto puede apreciarse con claridad en un original de transición donde se alternan las hojas que contienen los fragmentos en prosa "cortada» (la escansión es de puño y letra de la autora) con las del poema preexistente, «El trompo y el látigo». De esa versión final se encontraron cinco originales mecanografiados sucesivos, cada uno encarpetado, con correcciones y adiciones autógrafas, a las que se suman otras enmiendas y agregados transcriptos por Elena Ivulich (secretaria de Ocampo). Los títulos descartados antes de llegar al definitivo fueron: El trompo y el látigo, Prenatal corazón y Correspondencias. Asimismo, hay una copia mecanografiada del último de los cinco originales supervisados por la autora, sin encarpetar y con ligeras enmiendas manuscritas de Elena Ivulich. Hemos seguido esta versión, que presenta el texto más completo y limpio de todos los que hemos podido examinar, no sin cotejarla con las inmediatamente anteriores para subsanar posibles errores u omisiones en la transcripción. (Montequin, 2006:182-183).23

Como gran arconte, custodia, cuida y a la vez interpreta los archivos de Ocampo con toda la ley que le otorga su lugar de curador y lector muy familiarizado con el mundo de Silvina Ocampo, y su vínculo co-constitutivo de vida y obra; en este sentido afirma:

Si uno no está o no tiene una suficiente consistencia como lector para asumir una figura autoral, tomar 
esa decisión sin que pese, no merecés hacer esa tarea (...) autoral en el sentido en que estás trasladando, porque en el sentido de la autoría del texto no es así pero la decisión de que eso se conozca como obra literaria es de uno. (Montequin, 2021:s/p)

Como también lo prenatal, lo póstumo a modo de marca especial de la escritura de Invenciones del recuerdo, de igual forma que los otros textos ya editados y los inéditos todavía, parece conducirnos a las invenciones de origen, de lo previo, del «antes». No solo lo hace porque Montequin lee como trabajando en «capas geológicas o arqueológicas, sobre soportes o bajo superficies, pieles, viejas o nuevas», como señala Derrida sobre la práctica archivante, como buscando un inicio previo e inicial que inaugure y determine la legitimidad del archivo elegido para su edición — «el arco compositivo del primer borrador, segundo borrador, tercer borrador» (Montequin, 2021:s/ p)—; sino porque al ubicarse en el lugar de arconte hace pensar en dos elementos que supone la historia de esta actividad poderosa y creadora.

Ambos tienen que ver con la etimología de las palabras archivo y arconte. La primera (arkhé) remite tanto al origen, al principio de algo como a su dirección determinante, inscripta según la semántica del término en ese núcleo mismo desde donde lo originario dona principio y dirección. Derrida habla de Ley y mandato (1997:10). La segunda (arkheîon) alude a una residencia, la de ciudadanos cuyo poder político le concedía la autoridad de ser "guardianes» en sus casas de documentos a los que custodiaban en su materialidad original y frente a los cuales tenían «competencia hermenéutica» (1997:10). Dicha competencia tiene que ver con una ordenación, clasificación y fijación — «consignación» en palabras de Derrida (1997:11)— de esa materialidad informe de escritura en una reunión, en un archivo editable a partir del cual, en el caso de nuestro texto, surge Invenciones del recuerdo.

Luego de precisiones sobre el archivo que Derrida determina, da cuenta de que de pronto la noción de archivo se vuelve porosa. Como lo hacen las nociones de prenatal y póstumo. Por esto, desde esta perspectiva se iluminan de otra manera, ahora puestas en relación. Lo prenatal se vincularía con la escritura archivada y lo póstumo con la edición posterior al acto archivable. En ambos casos la invención de origen se despliega como en puntos extremos, de antes y después.

Por esto, quisiera recuperar y enfatizar dos ideas. Por un lado, siguiendo a Derrida:

\footnotetext{
Opongo aquí el rigor del concepto a lo vago o a la imprecisión abierta, a la relativa indeterminación de una noción semejante. «Archivo» es solamente una noción, una impresión asociada a una palabra (...). Tenemos solamente una impresión, una impresión insistente a través del sentimiento inestable de una figura móvil, de un esquema o de un proceso infinito e indefinido. (...) lo considero como la posibilidad y como el porvenir mismo, del concepto, como el concepto mismo del porvenir, si es que hay uno y si, como creo, el pensamiento del archivo depende de él. (1997:37)
}

Por otro lado, a la vez que reivindico la idea derridiana que amplía Anna Maria Guasch afirmando que el archivo no aspira a lo estable, sino que se refiere a una figura móvil que puede ser explicada como un intento de forma de ser (2013:167), también recupero la noción derridiana de «mal de archivo». El mal de archivo como un 
arder de pasión. No tener descanso, interminablemente, buscar el archivo allí donde se nos hurta (...). Es lanzarse hacia él con un deseo compulsivo, repetitivo y nostálgico, un deseo irreprimible de retorno al origen, una morriña, una nostalgia de retorno al lugar más arcaico del comienzo absoluto. (Derrida, 1997:98)

De este modo, Montequin hace honor con su mal de archivo —ostentado en su maravilloso trabajo de curador y editor como en sus descripciones meticulosas de los papeles ocampianos que revelan ese ardor al que se refiere Derrida - a la potencia prenatal que circula por Invenciones del recuerdo en las formas de la invención, el instinto, la infancia y la (im)potencia, hace perceptible ese acontecimiento de lo previo y lo porvenir de otro acontecimiento, póstumo. En ese arco entre la construcción de lo arcaico ocampiano y la construcción archivante-editada de su curadoreditor, entre lo prenatal y póstumo, entre el antes y el después, asistimos a la exploración de escrituras repletas de imprevistos y posibilidades.

Leer Invenciones del recuerdo entre pre y pos permite deslizarnos en lo inasible de su potencia, en el modo en que se alza una escritura que trasciende las clasificaciones de autobiografía como las categorías de sujeto, lenguaje, historia, autor, obra.

Buscando a Dios «como cuando jugaba al gallo ciego/ buscando puertas para escapar (Ocampo, 2006:172) Invenciones del recuerdo explora y dinamita los orígenes y los finales. Nacimientos y muertes. Y en ese gento los intensifica. Huye y queda en una tinta gris que, similar al humo, nos nubla y nos convoca a internarnos en sus letras para dar, tal vez, con un rostro, el rostro que, sin embargo no hará otra cosa más que seguir exponiendo palimpsestos y ardores.

\section{Conclusiones}

Invenciones del recuerdo escribe también la palabra «natal». Lo hace cuatro veces refiriéndose a la casa de la calle Viamonte.

Esa casa natal estaba compuesta por cuatro casas comunicadas entre sí a través de puertas espejo en lugares inauditos, donde habitaban tías y tíos y padres con hijas con hijos, «numerosa servidumbre», «libros, pálidos,/ o escribanos congestionados/ que entre anaqueles con biblioratos y papeles cuadriculados,/ escribían números» (Ocampo, 2006:16 17) y también «una familia de perros lanudos», «una docena de canarios» (17) pertenecientes a un tío viajero que llenaba la casa y las conversaciones con sus cartas. «La casa de los escritorios». «Pensaba en aquella casa como hoy piensa en el mundo» (17).

Esta casa podría ser una buena metáfora de los archivos y ediciones póstumos de Ocampo. ${ }^{24}$ Una escritura hecha de interiores y exteriores de otras escrituras, comunicadas entre sí, o ensayadas entre posibilidades, un territorio donde se sale y al salir se entra a otro interior o exterior, interminablemente. Una escritura que se practica, como lo hace el archivante arconte, tratando con la materialidad de los intersticios y de los rincones y a la vez custodiando en su residencia. Porque:

Silvina, en ese sentido, iba y volvía (...) hay una especie de marcha y contramarcha de temas, de motivos, de estilo, de tonos que se da a lo largo de las décadas y que es interesante ver cómo interactúa todo eso que, por otra parte, era como una necesidad de Silvina en sus propios libros, los libros que armaba (...) por ejemplo, de acuerdo a los manuscritos no a los textos publicados, tenés textos de Las invitadas de los 
años 30 cuando si vos tomás Las invitadas te parece que fueron cuentos escritos en su último período pero no. (Montequin, 2021:s/p)

$\mathrm{Ni}$ en esa casa natal de fragmentos y pasadizos, ni en ese ir y venir que también dan forma a lo prenatal, ni en el rostro dibujado, se nos ofrecerá el rostro de un autor que cuenta su historia infantil. No daremos con una autobiografía, o iremos mucho más allá de ella, a su invención.

La aproximación a lo prenatal, disperso además, con la misma palabra y también con imágenes que pueden intensificarlo («Prenatalmente, en el corazón», —Ocampo, 2014:186—; «La intimidad de un cuento es prenatal», —Ulla, 1982:33; en Podlubne, 2011:313—; «siempre escuché el cielo, el árbol y el rastrillo sobre las piedras como un recuerdo anterior a mi vida» —Ocampo, 2008:54-) condujo a las extrañezas de la invención ocampiana, al misterio desubjetivante de lo instintivo, al «sin voz» de la infancia, a la escritura (im)potente. Lo póstumo, por su parte, lleva a la pregunta por cuánto de lo prenatal de Invenciones del recuerdo se tensiona con el archivo, lo inédito y la edición.

En ese arco que mencionábamos más arriba queda el recorrido, la lectura de esa zona — derrumbada y explorada, acrónica, sin espacio totalizador, extensión de fragmentos, desmayos, infinitos- que acoge y deja acontecer la convivencia del no ser y el ser en su pura posibilidad y en su inolvidable incumplimiento. Esa zona que se interna en una selva especial, aquella que Agamben sabe describir tan bien:

Donde acaba el lenguaje empieza, no lo indecible, sino la materia de la palabra. Quien nunca ha alcanzado, como en un sueño, esta lignaria sustancia de la lengua, a la que los antiguos llamaban «selva» es, aunque calle, prisionero de las representaciones. (Agamben, 2002:17)

\section{Notas}

1 Existe, ciertamente, abundante bibliografía crítica sobre la obra que Silvina Ocampo publicó en vida. Sin embargo, se registra hasta el momento escasa bibliografía que se ocupe específicamente del corpus póstumo. Destacamos los trabajos de María Julia Rossi (2017, 2020), de Claudia Páez Lotero (2013); de Natalia Biancotto (2009); Graciela Tomassini (2010), Julia Muzzopappa (2017); Romina Magallanes (2020, 2021). Si bien estos trabajos, junto a conceptos teóricos, acompañan la lectura del presente artículo, es la tarea monumental y minuciosa realizada por el curador y editor del archivo Ocampo, Ernesto Montequin, la que lo inspira y fundamenta.

2 Natalia Biancotto propone que «Invenciones del recuerdo es una autobiografía que se construye contra los presupuestos de la autobiografía clásica. Dice Lejeune: "Para que haya autobiografía (y, en general, literatura íntima) es necesario que coincidan la identidad del autor, la del narrador y la del personaje" (1991:48). En Invenciones... ninguno coincide, y sobre esa no coincidencia Silvina Ocampo construye su escritura del yo» (2009:3).

3 Para Biancotto la clave para leer el texto: «la clave la da la propia definición de Silvina de su autobiografía como "historia prenatal". En lo críptico del concepto se pone de manifiesto algo obvio: es la historia de un yo incierto, que es anterior a Silvina Ocampo. Lejos de ser el relato que funda y se funda en el nombre propio, es una narración cuya datación es anterior a la del nombre propio» (2009:5).

4 Ocampo ve esta faceta de la escritura y la lengua de crear ser, no solo expresar lo. En Ejércitos de la oscuridad escribe: «Cualquier cosa que no existe y tiene un nombre termina por existir», entre otros ejemplos (2008:17).

5 Así también: «La cronología no existe en el tiempo del recuerdo» (Ocampo, 2006:28); «En realidad no sabe si en su 
recuerdo/se ha apropiado de ese tocado/ que podría pertenecer al traje de su hermana o de su prima./ La memoria suele ser ladrona» (141). «Y el tiempo, el tiempo, el tiempo/ con su rostro de mago (177).

6 También: «Cuando hablamos de invención necesariamente pensamos en un deus mortalis que, gracias a un gesto repleto de creatividad, potencia e imaginación, arroja a la existencia algo nuevo (...). Claro que aquí nos encontramos con el gran problema al que se enfrenta la invención entendida de este modo. Cuando un hombre de ciencia o un artista inventan (suponiendo aquí la más que discutible existencia de alguna diferencia excluyente entre ambos) inevitablemente deben insertarse en la tradición que los alberga. En otras palabras, si alguien inventara algo absolutamente nuevo, algo que no tuviera ningún tipo de relación con las normas y los estatutos vigentes, no sería reconocido como perteneciente al campo en el que viene a incorporar su buena nueva. Pensemos en un descubrimiento en el mundo de la física o en una creación literaria vanguardista que fueran completamente inesperados, inauditos, imprevisibles. Lamentablemente serían, por esa misma virtud, irreconocibles y quedarían así, definitivamente, sepultados en el barro del anonimato. Lo que hay, tal vez, sea otra invención, aquella que mantiene un vínculo ineludible con lo instituido, lo establecido y, desde allí, intenta otro imposible: hacer surgir la magia virginal de aquello que no responde al cálculo de la anticipación, el cual siempre nos condena a la eterna repetición de lo mismo. Claro que este descubrir puede dar lugar a un nuevo estatuto, una nueva institución y, así, todo vuelve a empezar» (Chun, 2019:6). «Inventar, etimológicamente, significa dejar venir, recuerda Derrida (1987:53-55). Descubrir es precisamente eso, sacar de la oscuridad algo pre-existente, quitarle el manto que lo mantenía en lo oculto» (12). «Inventar, sería entonces "saber" decir "ven" y responder al "ven" del otro. ¿Sucede alguna vez? De este evento no estamos nunca seguros» (93) (Cita de Derrida en Chun, 2019:19).

7 Dice Martín Heidegger en ¿Qué es eso de Filosofia?: «La tradición no nos entrega a una coerción de lo pasado (Vergangene) e irrevocable. Transmitir (uberliefern), delivrer, es un liberar, es decir, hacia la libertad de la conversación con lo sido (Gewesene)» (1969:19). En nota al pie, Adolfo Carpio explica: «Heidegger distingue entre das Vergangene, lo "pasado" ya definitivamente desaparecido, y das Gewesene, lo "sido", que sigue sin cesar vivo y activo» (1969:19).
8 En otro de sus libros póstumos, Ejércitos de la oscuridad, leemos: «Lo mejor fue siempre al principio un recuerdo, por eso no sabemos cuándo nació» (2008:18); «Se remienda la memoria con la invención: resulta más pobre, pero a veces más poética y real» (107).

9 El subrayado es propio.

10 Ese "mundo complementario», dice Agamben, es el de lo olvidado (2005:38): «Y esta parte tiene que ver con el fin de los tiempos, así como la negligencia no es otra cosa que un anticipo de la redención. Las torceduras, la joroba, las torpezas son la forma que sume las cosas en el olvido. Y aquello que nosotros hemos olvidado por siempre es el Reino, nosotros que vivimos "como si no fuéramos Reino"» (42). Escribe Ocampo: «vagando por la casa debajo de las alfombras/ como Odradek,/intenta huir, se queda/ en todas partes, en ninguna parte» (2006:11). Según Sergio Cueto, Odradek es nombre de lo olvidado: «Que ese nombre, aparte del nombre "cosa" no fuese, precisamente porque no nombre nada en particular, el nombre de la singularidad que no se puede nombrar, el inefable nombre la cosa, que ese nombre, pues, existe, se puede demostrar pronunciándolo. Ese nombre es Odradek. Odradek es el nombre de la cosa olvidada y la cosa tal como se olvida en el nombre. En Odradek la cosa encuentra una última residencia en el olvido y el hombre cuida, si no ya de la cosa, sí todavía de su olvido. Acaso la última vocación del hombre sea salvar las cosas perdidas, las cosas olvidadas (2018:23). En efecto, en Ocampo rondan estos pensamientos. En Ejércitos de la oscuridad escribe: «Hay ciertas formas de olvido que más que la memoria enriquecen el recuerdo (Ocampo, 2008:22); «El olvido total nos entrega las llaves de los secretos más inextricables» (143); «Hay poemas y músicas predilectas que jamás volvemos a encontrar: más que nuestro conocimiento, nuestro olvido las creó. Están en el aire y alguien las escribirá» (61).

11 Graciela Tomassini escribe sobre Ejércitos de la oscuridad: «La atracción de Silvina Ocampo por la escritura breve y fragmentaria aflora, "escondida", en textos como "Fragmentos del Libro Invisible" (Autobiografía de Irene, 1948), "El diario de Porfiria Bernal" (Las invitada, 1961) y "Anotaciones" (Cornelia frente al espejo, 1988) —entre otros ejemplos—. El volumen Ejércitos de la oscuridad (2008), que compendia notas y fragmentos en prosa encontrados en el vasto cuerpo de escritura inédita de la autora, viene ahora a confirmarla "No es que el fragmento tenga como horizonte la 'obra' como totalidad; es, en cambio, una 
palabra que se sitúa fuera del todo de “la literatura"” (2010:39). Además: «Como en Blanchot, el fragmento piensa y también pone en escena, "liberando al pensamiento de ser sólo pensamiento con vistas a la unidad" y no supone el horizonte cerrado o sistemático de un arte poética, sino más bien una insistencia en explorar, mediante la reiteración y la discontinuidad, el mundo líquido de las visiones nocturnas» (46).

12 Dice Biancotto: «En sus momentos más característicos, los relatos de Silvina Ocampo se definen menos por su "contenido" sobrenatural, anormal, irreal, etc., que por una forma de la escritura, una ética. Esa forma, si se la quiere imaginar, habría que situarla adentro de Wonderland, atravesada por el nonsense de Lewis Carroll y de Edward Lear; sería algo así como el resultado de escribir adentro del espejo. Ocampo siempre fue indiferente a las convenciones del género, sin embargo, sus críticos se empeñaron en adscribirla al fantástico; el debate sobre el género responde a un interés específico de la década del setenta, en el que se enmarca el libro de Todorov, que tiene un revival en los ochenta, sin embargo, seguimos aferrados a esa tendencia de análisis, ¿por comodidad? ¿por seguridad? En un contexto en el que los géneros tradicionales se retuercen por la inflexión de ciertas "vueltas" o "giros", según los modos actuales de interrogar los problemas de la literatura, ¿en qué medida es posible seguir hablando del género? Entonces, para leer esta literatura en nuevos términos, pienso en el nonsense como forma del relato, un modo de uso de la locura como estética y como ética. El nonsense de Carroll es la locura en el mundo, dice Aira (2004). Los relatos de Silvina Ocampo están atravesados por la locura y su reverso, la iluminación y la videncia. Con mayor intensidad en sus dos últimos libros, los personajes se hacen preguntas tan locas que parecen ingenuas, como las de Alicia, “¿Cómo se hace para saber si uno está soñando cuando todo parece tan real? (...) ¿Y cómo sabré, cuando despierte, que estoy realmente despierto?" ("Y así sucesivamente" —Ocampo, 2007:238—); o dicen cosas tan locas que parecen cómicas: “La miré como quien mira un detergente" ("El rival”, 2007:208). El nonsense en Silvina Ocampo es un modo de ver el mundo y un modo de estar en la escritura» (2015:44). La lectura de Biancotto resulta muy pertinente para ciertos momentos de Invenciones del recuerdo.

13 Para ampliar el sentido de la relación «originaria» entre dibujo y pintura ver Freire (2005:171), y Barthes (1989:13; 2009). Por otra parte, es interesante atender a la etimología del término grapho que, además de escritura abarca en su uso las prácticas de «arañar», «rayar», «pintar», «dibujar», términos que no suponen un logos previo, un concepto a comunicar, un juicio a expresar. Ocampo realizaba ambas actividades desde pequeña. Una de las reflexiones sobre esa relación se encuentra en una entrevista de 1975: «Fueron simultáneas, pintar y escribir. ¿Para quién la "A" no fue una casita, la "T" una vela encendida, la "C" una luna menguante, la "S" un cisne?» (2014:187).

14 La cursiva es propia.

15 Biancotto resalta esta idea: «A nivel temático y estructural Invenciones... señala la no continuidad del sujeto, del tiempo, del recuerdo. "La cronología no existe en el tiempo del recuerdo", dice la narradora (Ocampo, 2006:28), y el relato sustenta el precepto con sus idas y vueltas temporales, su puesta en imágenes de la fragmentariedad del recuerdo» (2009:7).

16 En «Isis» una niña se transforma en un animal al cruzar miradas con él (Ocampo, 2020:385 386); en «Azabache» una mujer apasionada por los caballos se convierte en una mujercaballo (256-258).

17 Liddell y Scott (1996:316, 759, 1057). Zoe «remite al "simple hecho de vivir, común a todos los seres vivientes"», bios, en cambio «"a la forma o manera de vivir propia de un individuo o de un grupo", al estilo de vida, a la vida ética y políticamente calificada» (Agamben en Castro, 2008:50).

18 Si bien existe siempre una articulación entre bios y zoe, en la escritura ocampiana se hace presente con mayor intensidad el devenir animal como proceso consustancial de la humanidad, es decir, como el revés del acontecimiento antropogénico, de nuestro estar continuamente llegando a ser hombres. Hay en sus textos un señalamiento de ese lazo indisoluble entre bíos y zoé, que es, al mismo tiempo, un señalamiento del contacto abisal entre vida y lenguaje.

19 Recordemos que Invenciones del recuerdo es un texto que cambia regularmente de la primera a la tercera persona.

20 Ver también Ferrero (2007:155) que en su reseña de Invenciones del recuerdo indica que se trata de una autobiografía novedosa no tradicional al modo en que la entiende Lejeune. Antes que una mímesis, Invenciones del recuerdo tendría que ver con una poiesis.

21 Esto opera en el texto, indica Biancotto, «mediante la elipsis del nombre propio, y de disociar narrador y personaje mediante la huida gramatical», un episodio «es ocasión de uno 
de los más flagrantes signos de lo que llamo "huida gramatical", la del "yo" que se muestra ocultándose en "ella". En el recuerdo de ese episodio, el sirviente Chango provoca la huida: "Yo lo recuerdo así,/ pero ella lo recuerda como el fantasma de una pesadilla,/ como el símbolo del infierno" (2006:117)» (2009:6).

22 Sobre la infancia en Invenciones del recuerdo apunta María Julia Rossi: «De este modo, lo que procura recobrar no es la impoluta mirada infantil, sino establecer un pacto de colaboración con ella que permita escapar del verosímil realista, expandiendo el punto de vista más allá de la mímesis individual. Lejos de un intento de recuperar una inocencia perdida, la visión se ahonda al recobrar percepciones infantiles largamente obturadas» (2020:90).

23 En la compilación de diversos textos - algunos póstumos otros editados en vida de Ocampo-El dibujo del tiempo, Montequin introduce un texto breve denominado, también, «Invenciones del recuerdo». Es un texto en prosa de cuatro páginas donde Ocampo se dedica a escribir sobre Catalina Iparaguirre, una de sus niñeras. Lo significativo es «La nota al texto» final, donde, como en Invenciones del recuerdo, detalla, describe la materialidad del original: «Se conservan: a) borrador autógrafo en lápiz y bolígrafo azul (ca. 1958-1960), escrito en un cuaderno donde hay borradores de algunos cuentos de Las invitadas (1961); b) original dactilografiado con correcciones y adiciones autógrafas en lápiz y bolígrafo azul, 3 hojas; c) original dactilografiado, con correcciones y adiciones autógrafas en tinta azul, y otras transcriptas por Elena Ivulich (secretaria de Silvina Ocampo), 3 hojas; d) original dactilografiado con correcciones y adiciones autógrafas en bolígrafo azul, adiciones transcriptas por Ivulich en tinta azul, 4 hojas; e) copia dactilografiada (ca. 1970-1980), con adiciones autógrafas en bolígrafo azul y lápiz, 3 hojas; y f) copia dactilografiada (ca. 1970-1980), 3 hojas. Se sigue de esta última. Como lo indica su título, este texto y el siguiente parecen haber sido escritos originariamente como parte de las versiones en prosa de los recuerdos de infancia de la autora, que luego convergen en la autobiografía en verso Invenciones de recuerdo, publicada en 2006. Para una breve descripción del proceso de escritura de Invenciones del recuerdo, véase la "Nota al texto" que cierra el volumen» (2014:375-376).

24 Rossi resalta, respecto de Invenciones del recuerdo, a «la casa como experiencia» (2020:90).

\section{Referencias}

Agamben, G. (2002). Idea de la prosa. Madrid: Editorial Nacional.

Agamben, G. (2005). Profanaciones. Buenos Aires: Adriana Hidalgo.

Agamben, G. (2007). Infancia e historia. Destrucción de la experiencia y origen de la historia. Buenos Aires: Adriana Hidalgo.

Agamben, G. (2008). La potencia del pensamiento. Buenos Aires: Adriana Hidalgo.

Artiéres, P. (2019). La experiencia escrita. Estudios sobre la cultura escrita contemporánea (1871-1981). Buenos Aires: Ampersand.

Barthes, R. (1989). Variaciones sobre la escritura. La escritura y la etimología del mundo (11-78). Buenos Aires: Sudamericana.

Barthes, R. (2009). Lo obvio y lo obtuso. Imágenes, gestos y voces. Barcelona: Paidós.

Biancotto, N. (2009). En torno al nombre (im)propio: las autobiografías de Silvina y Victoria Ocampo. Actas del II Congreso Internacional de Cuestiones Críticas. Rosario. Facultad de Humanidades y Artes. Universidad Nacional de Rosario.

Biancotto, N. (2015). Del fantástico al nonsense: Sobre la narrativa de Silvina Ocampo. Orbis Tertius, 2O(21), 39-50.

Cassin, B. (2008). El efecto sofístico. Buenos Aires: Fondo de Cultura Económica.

Castro, E. (2008). Giorgio Agamben. Una arqueología de la potencia. Buenos Aires: UNSAM.

Chartier, R. (2018). Las revoluciones de la cultura escrita. Barcelona: Gedisa.

Chun, S. (2019). Inventar el imposible porvenir: estética y política. El taco en la brea, (10), 5-16. 
Cueto, S. (2018). Intimidad de las cosas. Rosario: Nube negra [impar].

Deleuze, G. (1996). Crítica y clínica. Buenos Aires: Anagrama.

Deleuze, G. y Guattari, F. (2004). Mil Mesetas. Capitalismo y esquizofrenia. Valencia: Pretextos.

Derrida, J. (1997). Mal de archivo. Una impresión freudiana. Madrid: Trotta.

Ferrero, A. (2007). Invenciones del recuerdo by Silvina Ocampo. Journal Article Review. Chasqui, 36(1), 155-158.

Freire, H. (2005). La escritura: ¿espacio liso o estriado? Escritura e imagen, (1), 159-177.

Guasch, A.M. (2013). Arte y archivo, 1970-2010. Genealogías, tipologías y discontinuidades. Madrid: Akal.

Heidegger, M. (1969). ¿Qué eso de filosofía? Buenos Aires: Sur.

Lejeune, P. (1974). Le pacte autobiographique. París: Du Seuil.

Levinas, E. (1995). De otro modo que ser, o más allá de la esencia. Salamanca: Sígueme.

Levinas, E. (1997). Totalidad e infinito. Ensayo sobre la exterioridad. Salamanca: Sígueme.

Liddell, H. y Scott, R. (1996). Greek English Lexicon. Oxford: Oxford University Press.

Magallanes, R. (2020). Intersticios de lo póstumo. La escritura como exploración minúscula de sí, en Ejércitos de la oscuridad de Silvina Ocampo. Boletín 20 del Centro de Estudios de Teoría y Crítica literaria. Rosario: Universidad Nacional de Rosario, 184-196.

Magallanes, R. (2021a). Escrituras en juego. Libros póstumos. La experiencia Ocampo/Montequin. Estudios de teoría literaria. Artes, letras y humanidades, 10(23). Mar del Plata: Universidad Nacional de Mar del Plata. En prensa.

Magallanes, R (2021b). La promesa, de Silvina Ocampo, como escritura imposible o lo imposible como escritura. Pasavento. Revista de estudios hispánicos. Alcalá: Universidad de Alcalá. En prensa.

Molloy, S. (1996). Acto de presencia. La escritura autobiográfica en Hispanoamérica. México: Fondo de Cultura Económica.

Montequin, E. (2006). Nota preliminar - Nota al texto. Invenciones del recuerdo. Buenos Aires: Sudamericana.

Montequin, E. (2014). Nota al texto. El dibujo del tiempo. Recuerdos, prólogos, entrevistas. Buenos Aires: Lumen.

Montequin, E. (2021). Conversación Ernesto Montequin y Romina Magallanes. Buenos Aires. Inédito.

Muzzopappa, J. (2017). Irrupciones de la infancia. La narrativa de Silvina Ocampo. Buenos Aires: Corregidor.

Ocampo, S. (2006). Invenciones del recuerdo. Buenos Aires: Sudamericana.

Ocampo, S. (2008). Ejércitos de la oscuridad. Buenos Aires: Sudamericana.

Ocampo, S. (2011). Las repeticiones y otros relatos inéditos. Buenos Aires: Lumen.

Ocampo, S. (2014). El dibujo del tiempo. Recuerdos, prólogos, entrevistas. Buenos Aires: Lumen.

Ocampo, S. (2020). Cuentos completos. Buenos Aires: Emecé.

Páez Lotero, C. (2013). Estructuras desbordantes en Silvina Ocampo. Invenciones del recuerdo como poema largo. Masters Theses 1911. February 2014. 1000. fromhttps://scholarworks.umass.edu/theses/1000.

Podlubne, J. (2011). Escritores de Sur. Los Inicios literarios de José Bianco y Silvina Ocampo. Rosario: Beatriz Viterbo.

Podlubne, J. (2013). La visión de la infancia en los cuentos de Silvina Ocampo. Confluenze, 5(2), 97-106.

Rosa, N. (1990). El arte del olvido. Buenos Aires: Puntosur.

Rossi, M.J. (2017). Una «fidelidad involuntaria»: la reescritura en Silvina Ocampo. Saga. Revista de letras, (7), 1-23.

Rossi, M.J. (2020). Ficciones de la emancipación. Los sirvientes literarios de Silvina Ocampo, Elena Garro y Clarice Lispector. Rosario: Beatriz Viterbo.

Sanhueza, L. (2018). La partida fantasma. Apuntes sobre la vocación literaria. Córdoba: Ediciones DocumentA/ Escénicas. 
Tomassini, G. (2010). Mariposas nocturnas: fragmento, reescritura y minificción en Ejércitos de la oscuridad, de Silvina Ocampo. Cuadernos del CILHA, 11(13), 38-47.

Yelin, J. (2015). La letra salvaje. Ensayos sobre literatura y animalidad. Rosario: Beatriz Viterbo. 